\title{
EFFECT OF OVARIECTOMY AND OF VARIOUS HORMONES ON THE SYNTHESIS OF PROGESTERONE BY THE GUINEA-PIG PLACENTA IN VITRO
}

\author{
J. R. BEDWANI* AND P. B. MARLEY \\ Department of Pharmacology, The School of Pharmacy, London
}

(Received 5th October 1970)

\begin{abstract}
Summary. Placental slices from intact and ovariectomized guinea-pigs, incubated in Krebs-Ringer solution containing nicotinamide and NAD, synthesized no progesterone de novo but were able to convert pregnenolone to progesterone.

Placental slices from animals ovariectomized 6 days before the incubation synthesized twice as much progesterone from pregnenolone $(16 \mu \mathrm{g} / \mathrm{g} / 3 \mathrm{hr})$ as slices from intact animals $(7 \mu \mathrm{g} / \mathrm{g} / 3 \mathrm{hr}, P<0.01)$. This suggests that the $3 \beta$-hydroxysteroid dehydrogenase activity of the placenta increases after ovariectomy.

Cyclic AMP significantly reduced the conversion of pregnenolone to progesterone $(P<0.02)$, whereas gonadotrophic hormones (LH, or a combination of HCG and PMSG) and prostaglandins $E_{1}$ and $F_{2} \alpha$ had no effect in vitro.
\end{abstract}

\section{INTRODUCTION}

The guinea-pig placenta may have endocrine functions similar to those of the human placenta, since ovariectomy after the first half of pregnancy does not necessarily lead to abortion (Herrick, 1928; Amoroso, 1955). Further evidence for this comes from the observation that the concentration of progesterone in uterine venous blood from ovariectomized animals is greater than that in systemic arterial blood (Heap \& Deanesly, 1966) though histochemical and biochemical techniques have failed to show the presence of $3 \beta$-hydroxysteroid dehydrogenase in the guinea-pig placenta at this time (Heap \& Deanesly, 1966; Ferguson \& Christie, 1967). This enzyme is necessary for the conversion of pregnenolone to progesterone.

The present experiments were designed to investigate the ability of placental slices from intact and ovariectomized guinea-pigs to synthesize progesterone in vitro, in the presence of various precursors and other substances known to affect steroidogenesis.

\section{MATERIALS AND METHODS}

Animals

Placentae were obtained from fourteen guinea-pigs of the Dunkin Hartley

* Present address: Department of Pharmacology, University of Cambridge. 
strain. Seven of the guinea-pigs were ovariectomized 6 days before use, under sodium pentobarbitone anaesthesia, and four of these received $10 \mathrm{mg}$ progesterone subcutaneously immediately after operation.

The guinea-pigs were 35 to 60 days pregnant on the day of the experiment judging from the data on placental weights given by Heap \& Deanesly (1966). The weights of the foetuses and placentae of each guinea-pig were recorded.

\section{Incubation}

Guinea-pigs were killed by cervical dislocation and the placentae were rapidly dissected out into ice-cold Krebs-Ringer solution. The placentae from individual animals were cut into slices $0.6 \mathrm{~mm}$ thick, using a McIlwain tissue chopper, and placed in ice-cold Krebs-Ringer solution. Approximately $0.6 \mathrm{~g}$ of the sliced tissue was weighed into flasks containing incubation medium and incubated at $37^{\circ} \mathrm{C}$ in a metabolic shaker, gassing continuously with $5 \% \mathrm{CO}_{2}$ in $\mathrm{O}_{2}$. After a 3-hr incubation, the contents of the flasks were alkalinized by the addition of $0.25 \mathrm{ml}$ of $\mathrm{N}-\mathrm{NaOH}$, and were then stored at $-20^{\circ} \mathrm{C}$ before extraction.

The incubation medium consisted of $10 \mathrm{ml}$ Krebs-Ringer solution containing nicotinamide $(10 \mathrm{mg} / \mathrm{ml})$ and nicotinamide adenine dinucleotide (NAD, 0.3 mg/ml) (Pearlman, Cerceo \& Thomas, 1954). In some experiments, plasma obtained from the guinea-pig just before death was used.

When appropriate, other additions to the incubation medium were as follows: $0.1 \mathrm{ml}$ of a $5 \mathrm{mg} / \mathrm{ml}$ solution of pregnenolone acetate in ethanol (to give a saturated solution of the steroid in the incubation medium), luteinizing hormone (NIH-LH-s11, $2 \mu \mathrm{g} / \mathrm{ml}$ ), human chorionic gonadotrophin (HCG, Pregnyl, Organon, 2 i.u. $/ \mathrm{ml}$ ) and pregnant mare's serum gonadotrophin (PMSG, Gestyl, Organon, 2 i.u. $/ \mathrm{ml})$, prostaglandin $\mathrm{E}_{1}$ or $\mathrm{F}_{2} \alpha(1$ and $10 \mu \mathrm{g} / \mathrm{ml})$ and cyclic $3^{\prime}, 5^{\prime}$ AMP ( $1.65 \mathrm{mg} / \mathrm{ml}$, i.e. $\left.5 \mathrm{~mm}\right)$.

\section{Extraction and assay of progesterone}

The contents of each flask were homogenized and diluted to $20 \mathrm{ml}$ with water. Progesterone was extracted by the method described by Dorrington \& Kilpatrick (1966), with the addition of an extra stage. The dry ether residues were partitioned between equal volumes of $n$-heptane and water, the aqueous phase being discarded. This was necessary to remove nicotinamide, which interfered with thin layer chromatography.

The final dry residue from the solvent extraction procedure was subjected to two dimensional thin layer chromatography (Armstrong, O'Brien \& Greep, 1964). Progesterone was located on chromatograms by observation under ultra-violet light $(254 \mathrm{~nm})$ and the appropriate areas of silica gel eluted with $2.5 \mathrm{ml}$ of methanol. Quantification of the extracted progesterone was by light absorption at $240 \mathrm{~nm}$, using a double beam recording spectrophotometer (Unicam SP 800 B).

The authenticity of the progesterone extracted above was confirmed using an LKB 9000 gas chromatograph-mass spectrometer. Retention times and mass spectra of extracted samples were indistinguishable from those of authentic progesterone (Text-fig. 1). 
Using the methods described, the recovery of $25 \mu \mathrm{g}$ progesterone incubated with placental slices in the absence of added pregnenolone was $66 \% \pm 10$ (mean \pm S.D., $n=4$ ). The results which follow are not corrected for recovery.

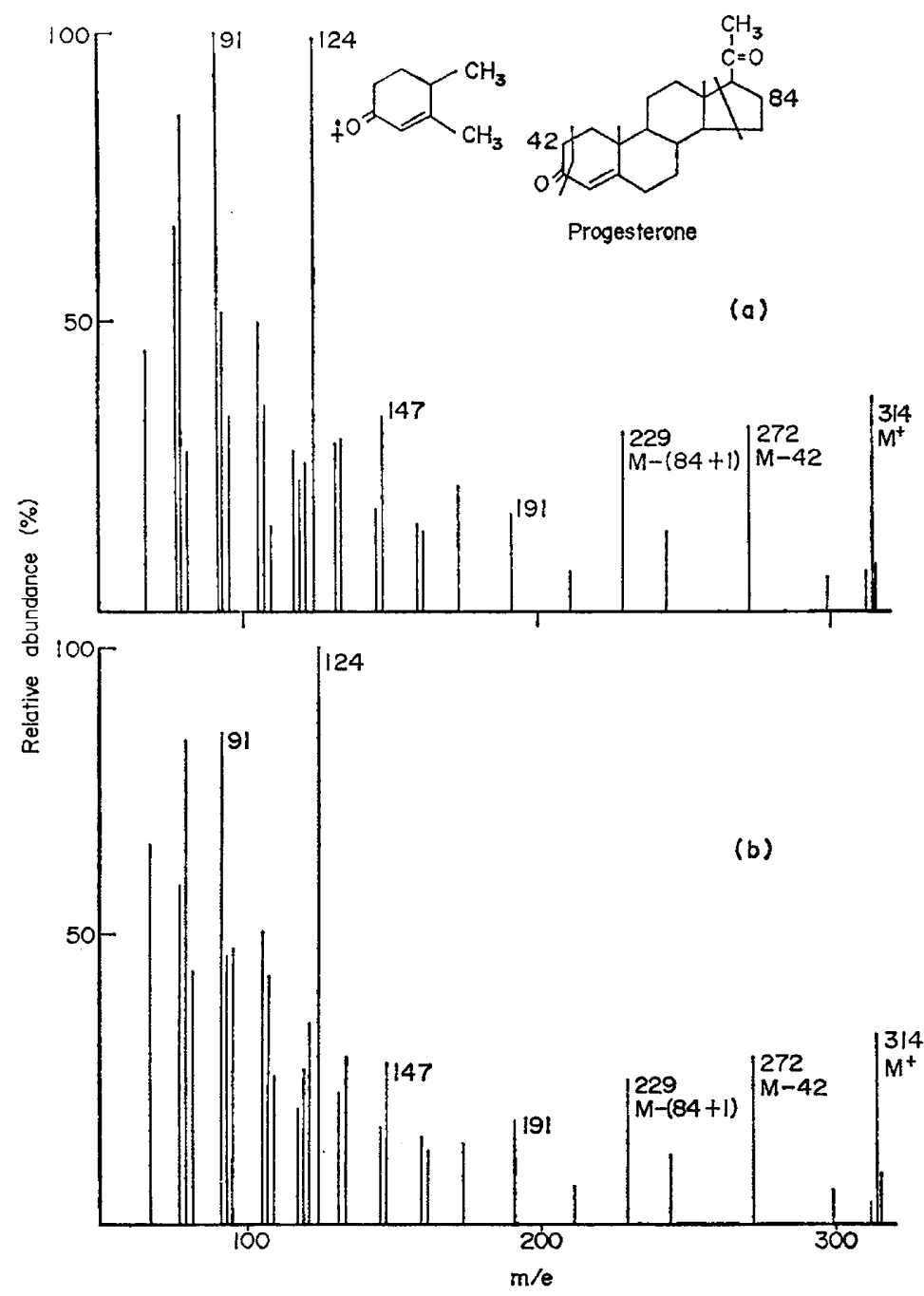

TexT-FIG. 1. Line diagrams from mass spectra of (a) authentic progesterone and (b) a sample of the steroid extracted from guinea-pig placental slices incubated with pregnenolone. The origin of the major peaks at mass to charge ratio (m/e) 272, 229 and 124 is indicated.

\section{RESULTS}

In the absence of pregnenolone, placental slices from intact and ovariectomized guinea-pigs synthesized no progesterone de novo (limit of detection $1.5 \mu \mathrm{g}$ ) when incubated in Krebs-Ringer solution (Table 1) or maternal plasma. In the presence of pregnenolone, the placental slices synthesized progesterone in 
amounts ranging from 3.9 to $22 \mu \mathrm{g} / \mathrm{g}$. No progesterone was detected in incubates containing pregnenolone but lacking placental slices (four experiments).

In the presence of pregnenolone, placentae from ovariectomized guinea-pigs synthesized more than twice as much progesterone $(16 \cdot 0 \pm 5 \cdot 3 \mu \mathrm{g} / \mathrm{g})$ as placentae from intact animals $(7 \cdot 0 \pm 3 \cdot 4, P<0.01$, Table 1$)$. Of the ovariectomized animals, it appeared that placentae from the three guinea-pigs which were not given progesterone after operation were more efficient at converting pregnenolone

TABle 1

STIMULANT EFFECT OF OVARIECTOMY, AND LAGK OF EFFECT OF GONADOTROPHIG HORMONES, ON THE RATE OF CONVERSION OF PREGNENOLONE TO PROGESTERONE BY PLACENTAL SLIGES

\begin{tabular}{|c|c|c|c|c|}
\hline \multirow{2}{*}{$\begin{array}{c}\text { Mean } \\
\text { foetal } \\
\text { wt }(g)\end{array}$} & \multirow{2}{*}{$\begin{array}{c}\text { Mean } \\
\text { placental } \\
w t(g)\end{array}$} & \multicolumn{3}{|c|}{ Progesterone content $\dagger(\mu g / g / 3 \mathrm{hr})$} \\
\hline & & $\begin{array}{c}\text { No } \underset{L H, H C G}{\mathrm{P}} \text { or } \\
P M S G\end{array}$ & With $L H$ & $\begin{array}{l}\text { With } H C G \\
\text { and PMSG }\end{array}$ \\
\hline $\begin{array}{l}37 \\
43 \\
58 \\
59 \\
60 \\
65 \\
82\end{array}$ & $\begin{array}{l} \\
2.9 \\
3.9 \\
2.9 \\
3.6 \\
4.2 \\
4.8 \\
5.6\end{array}$ & $\begin{array}{l}4 \cdot 1 \pm 2 \cdot 1(2) \\
\ddagger 14 \cdot 0 \\
7 \cdot 3 \pm 3 \cdot 6(2) \\
4 \cdot 0 \\
\ddagger 5 \cdot 6 \\
7 \cdot 9 \pm 0 \cdot 4(2) \\
5 \cdot 9 \pm 0 \cdot 1(2)\end{array}$ & $\begin{array}{r}5 \cdot 0 \\
\ddagger 13.8 \\
5.8 \\
3.9 \\
74.6 \\
10 \cdot 2 \\
6.0\end{array}$ & $\begin{array}{r}5 \cdot 8 \\
\ddagger 14 \cdot 6 \\
4 \cdot 5 \\
4 \cdot 3 \\
\$ 4 \cdot 0 \\
8 \cdot 3 \\
7 \cdot 7\end{array}$ \\
\hline \multicolumn{2}{|c|}{ Mean \pm S.D. } & $7 \cdot 0 \pm 3 \cdot 4$ & $7 \cdot 0 \pm 3 \cdot 6$ & $7 \cdot 0 \pm 3 \cdot 7$ \\
\hline $\begin{array}{c}\text { Ovar } \\
40 \\
44 \\
49 \\
\$ 60 \\
\$ 61 \\
90 \\
\$ 113\end{array}$ & $\begin{array}{r}\text { omized } \\
4 \cdot 0 \\
4 \cdot 1 \\
3 \cdot 5 \\
4 \cdot 2 \\
5 \cdot 8 \\
4 \cdot 2 \\
6 \cdot 1\end{array}$ & $\begin{array}{r}7 \cdot 3 \pm 0 \cdot 4(2) \\
10 \cdot 1 \pm 1 \cdot 8(5) \\
16 \cdot 3 \pm 5 \cdot 0(3) \\
19 \cdot 0 \\
21.8 \pm 3 \cdot 6(5) \\
17 \cdot 6 \pm 1 \cdot 6(5) \\
+19 \cdot 6\end{array}$ & $\begin{array}{r}10 \cdot 2 \\
13 \cdot 7 \\
10 \cdot 5 \\
20 \cdot 8 \\
15 \cdot 1 \\
14 \cdot 6 \\
\ddagger 22 \cdot 0\end{array}$ & $\begin{array}{r}10.6 \\
11.0 \\
11.4 \\
18.6 \\
10.9 \\
15.0 \\
\ddagger 21.2\end{array}$ \\
\hline \multicolumn{2}{|c|}{ Mean \pm S.D. } & $16 \cdot 0 \pm 5 \cdot 3^{* *}$ & $15 \cdot 3 \pm 4 \cdot 6 * *$ & $14 \cdot 1 \pm 4 \cdot 3^{* *}$ \\
\hline
\end{tabular}

$\dagger$ Mean \pm S.D. Number of replicates in parentheses, otherwise one.

In replicate flasks lacking pregnenolone, no progesterone was detectable (limit of detection $1.5 \mu \mathrm{g}$ ).

$\$$ No progesterone given after operation.

** Significantly different from the corresponding means for the intact animals, $P<0.01$ (Student's $t$ test).

to progesterone than placentae from those animals which received this treatment. However, from our data, the difference between the levels of progesterone produced is not significant $(0 \cdot 1>P>0.05$, Student's $t$ test). The gonadotrophic hormones LH and HCG plus PMSG did not significantly alter the yield of progesterone produced by the placental slices (Table 1). Placental slices, from an ovariectomized animal, incubated in the presence of cyclic AMP synthesized significantly less $(31 \%)$ progesterone than controls incubated in the absence of the cyclic nucleotide $(15 \cdot 3 \pm 3.3$ and $21 \cdot 8 \pm 3.6 \mu \mathrm{g} / \mathrm{g} / 3 \mathrm{hr}$, respectively, mean \pm S.D., $\mathrm{n}=5, P<0.02$, Student's $t$ test). Prostaglandins $\mathrm{E}_{1}$ and $\mathrm{F}_{2} \alpha$ had no significant effect compared with controls, at concentrations of $1 \mu \mathrm{g} / \mathrm{ml}(17 \cdot 3 \pm$ $1 \cdot 3,17 \cdot 2 \pm 1 \cdot 8$ and $17 \cdot 6 \pm 1 \cdot 6 \mu \mathrm{g} / \mathrm{g} / 3 \mathrm{hr}$, respectively, $\mathrm{n}=5)$ or $10 \mu \mathrm{g} / \mathrm{ml}(9 \cdot 7 \pm 1 \cdot 1$, 
$11 \cdot 2 \pm 2 \cdot 0$ and $10 \cdot 1 \pm 1 \cdot 8 \mu \mathrm{g} / \mathrm{g} / 3 \mathrm{hr}$, respectively, $\mathrm{n}=5$ ) using placentae from two ovariectomized guinea-pigs (for details of the guinea-pigs used see Table 1).

\section{Synthesis of progesterone by guinea-pig adrenal and ovarian tissues}

The steroidogenic activity of these tissues was investigated under the same conditions as those used for the placental incubations. Approximately $100 \mathrm{mg}$ of tissue were used in each flask.

Foetal and maternal adrenal tissues produced no detectable progesterone (limit of detection 1.5 $\mu \mathrm{g}$ ) in the absence of added pregnenolone, but produced very large amounts compared with placental slices when pregnenolone was present. Similarly, maternal ovaries synthesized no detectable progesterone de novo but converted pregnenolone to progesterone in relatively high yield in comparison to placental tissue (Table 2).

TABLE 2

THE CONVERSION OF PREGNENOLONE TO PROGESTERONE BY GUINEA-PIG ADRENAL AND OVARIAN TISSUES

\begin{tabular}{l|c}
\hline \multicolumn{1}{c|}{ Tissue } & $\begin{array}{c}\text { Progesterone content* } \\
(\mu \mathrm{g} / \mathrm{g} / 3 \mathrm{hr})\end{array}$ \\
\hline Foetal adrenals & $\dagger 910$ \\
& 313 \\
& $\dagger 748$ \\
Maternal adrenals & $\dagger 1929 \pm 244(4)$ \\
& $2047 \pm 46 \quad(4)$ \\
Maternal ovaries & $1776 \pm 163(3)$ \\
& $\dagger 94 \pm 10 \quad(2)$ \\
& $\dagger 105 \pm 18 \quad(2)$ \\
\hline
\end{tabular}

* Mean \pm S.D. Number of replicates in parentheses, otherwise one.

† In comparable flasks lacking pregnenolone, no progesterone was detectable (limit of detection 1.5 $\mu \mathrm{g})$.

\section{DISCUSSION}

Our experiments show that guinea-pig placental slices can convert pregnenolone to progesterone in vitro, in relatively small yield on a weight basis compared with adrenal and ovarian tissues. The slices were unable to synthesize detectable amounts of progesterone from endogenous precursors or from precursors present in the maternal plasma.

The ability of the placental slices to convert pregnenolone to progesterone indicates the presence of a $3 \beta$-hydroxysteroid dehydrogenase in the tissue. The activity of this enzyme appears to increase markedly following ovariectomy but the mechanism by which this occurs is not known. The increased amount of progesterone synthesized was not due to synthesis de novo, since no progesterone was produced in the absence of pregnenolone, nor was it due to a difference in sensitivity to gonadotrophic hormones since these had no effect in vitro. Possibly, the activity of the enzyme may be governed by the level of progesterone in the 
circulation since progesterone levels would fall immediately after ovariectomy. It is interesting that the enzyme activity did not appear to have increased to the same extent in those animals which received progesterone immediately after ovariectomy.

Cyclic 3',5' AMP had an inhibitory effect on the conversion of pregnenolone to progesterone. This was presumably mediated by depression of $3 \beta$-hydroxysteroid dehydrogenase activity, as has been demonstrated in rat adrenal and ovarian preparations (Koritz, Yun \& Ferguson, 1968; Sulimovici \& Boyd, 1969).

Prostaglandins $E_{1}$ and $F_{2} \alpha$, which are present in human amniotic fluid (Karim \& Devlin, 1967) did not alter the amount of progesterone produced in our experiments. Prostaglandin $F_{2} \alpha$ has been shown to increase the production of progesterone by rat ovaries incubated in vitro (Pharriss, Wyngarden \& Gutknecht, 1968) and prostaglandin $\mathrm{E}_{1}$ decreases progesterone production by rabbit ovaries in the presence of LH (Bedwani, unpublished results) but it is likely that these effects are exerted at stages before the conversion of pregnenolone to progesterone.

Considering that placentae from ovariectomized guinea-pigs synthesized a mean of $16 \mu \mathrm{g}$ progesterone $/ \mathrm{g} / 3 \mathrm{hr}$ from pregnenolone, and allowing for the total amount of tissue present (10 to 20 g/guinea-pig) and a $66 \%$ recovery, it would appear that the placenta in this species has the ability to produce sufficient progesterone to maintain pregnancy, provided there is an adequate supply of precursor steroids. In humans, these precursors are obtained from the maternal and foetal blood (Diczfalusy, 1969).

\section{ACKNOWLEDGMENTS}

We are indebted to the National Institutes of Health, U.S.A., for a gift of luteinizing hormone, and to Dr J. E. Pike of the Upjohn Company, Kalamazoo, Michigan, for supplies of prostaglandins $E_{1}$ and $F_{2} \alpha$.

Dr G. J. Thompson performed the gas chromatography-mass spectrometry and we gratefully acknowledge his help.

\section{REFERENCES}

Amoroso, E. C. (1955) Endocrinology of pregnancy. Br. med. Bull. 11, 117.

Armstrong, D. T., O'Brien, J. \& GreeP, R. O. (1964) Effects of luteinizing hormone on progestin biosynthesis in the luteinized rat ovary. Endocrinology, 75, 488.

Diczralusy, E. (1969) Steroid metabolism in the human foeto-placental unit. Acta endocr., Copenh. 61, 649.

Dorrington, J. H. \& Kilpatrick, R. (1966) Effects of pituitary hormones on progestational hormone production by the rabbit ovary in vivo and in vitro. 7 . Endocr. $35,53$.

Ferguson, M. M. \& Christie, G. A. (1967) Distribution of hydroxysteroid dehydrogenases in the placentae and foetal membranes of various mammals. F. Endocr. 38, 291.

Heap, R. B. \& Deanesly, R. (1966) Progesterone in systemic blood and placentae of intact and ovariectomized pregnant guinea pigs. $\mathcal{F}$. Endocr. 34, 417.

HerRick, E. H. (1928) The duration of pregnancy in guinea pigs after removal and also after transplantation of the ovaries. Anat. Rec. 39, 193.

KARm, S. M. M. \& Devin, J. (1967) Prostaglandin content of amniotic fluid during pregnancy and labour. F. Obstet. Gynaec. Br. Commonw. 74, 230.

Koritz, S. B., Yun, J. \& Ferguson, J. J., JR (1968) Inhibition of adrenal progesterone biosynthesis by 3', 5'-cyclic AMP. Endocrinology, 82, 620. 
Pearlman, W. H., Cerceo, E. \& Thomas, M. (1954) The conversion of pregnenolone to progesterone by homogenates of human placental tissue. F. biol. Chem. 208, 231.

Pharriss, B. B., Wyngarden, L. J. \& GutKnecht, G. D. (1968) Biological interactions between prostaglandins and luteotropins in the rat. In: Gonadotropins 1968, pp. 121-129. Ed. E. Rosemberg. Geron-X, Los Altos, California.

Sulrmovici, S. \& Boyd, G. S. (1969) The $\Delta^{5}-3 \beta$-hydroxysteroid dehydrogenase of rat ovarian tissue. The effect of adenosine 3',5'-cyclic monophosphoric acid. Eur. F. Biochem. 7, 549. 